Max-Planck-Institut für demografische Forschung

Max Planck Institute for Demographic Research

Konrad-Zuse-Strasse 1 - D-18057 Rostock - GERMANY

Tel +49 (0) 3812081 - 0; Fax +49 (0) 3812081 - 202;

http://www.demogr.mpg.de

MPIDR WORKING PAPER WP 2014-002

JANUARY 2014

\title{
Social Norms, Economic Conditions and Spatial Variation of Childbearing within Cohabitation across Europe
}

\author{
Trude Lappegård \\ Sebastian Klüsener (kluesener@demogr.mpg.de) \\ Daniele Vignoli
}

This working paper has been approved for release by: Frans Willekens (willekens@demogr.mpg.de), Head of the Research Group on International Migration.

(C) Copyright is held by the authors.

Working papers of the Max Planck Institute for Demographic Research receive only limited review. Views or opinions expressed in working papers are attributable to the authors and do not necessarily reflect those of the Institute. 
Social Norms, Economic Conditions and Spatial Variation of Childbearing within Cohabitation across Europe

Trude Lappegård ${ }^{\ddagger}$, Sebastian Klüsener ${ }^{\sharp \dagger}$, Daniele Vignoli ${ }^{\text {tł }}$

${ }^{*}$ Statistics Norway

${ }^{+1}$ Max Planck Institute for Demographic Research

t+ University of Florence, DiSIA - Department of Statistics, Informatics, Applications 


\begin{abstract}
Childbearing within cohabitation has gained considerable ground in recent decades, but existing explanations for this development are not coherent. Proponents of the Second Demographic Transition framework interpret it rather as a pattern of progress driven by processes such as emancipation from traditional social norms. Others see rises in childbearing in cohabitation being related to a "pattern of disadvantage" as they are often concentrated among individuals faced with blocked opportunities. In this paper we argue that these inconsistencies might stem from a gap in knowledge how the relevance of existing theories varies dependent on whether we look at variation in family formation behavior across individuals, subnational regions or countries. To test this hypothesis we revisit the existing theories by analyzing harmonized survey data from 16 European countries using a three-level hierarchical model. Our results suggest that the Second Demographic Transition framework is particularly important to understanding variation between countries, while pattern of disadvantage hypotheses seem more relevant to understanding variation between individuals and subnational regions.
\end{abstract}

\title{
Acknowledgements
}

The authors would like to thank Sandra Krapf for input and feedback on earlier versions of this paper. 


\section{Introduction}

One of the most remarkable changes in family formation behavior over the past 50 years is that marriage and childbearing are becoming increasingly disconnected. In this process, the incidence of (premarital) cohabitation and transition to parenthood within nonmarital co-residential unions has gained considerable ground (Kiernan 2004; PerelliHarris et al. 2012). These demographic changes have affected populations in Europe and America as well as Australia and Oceania (Lesthaeghe 2010). However, the timing of the onset and the intensity of the increases of cohabitation and childbearing within cohabitation, as well as the socio-economic characteristics of cohabiters vary across space and time (see, for example, Perelli-Harris et al. 2012; Esteve, Lesthaeghe, and López-Gay 2012; Ní Bhrolcháin and Beaujouan 2013). To the spatio-temporal variation in this process contributed that demographic changes are dependent on compositional characteristics of populations and prevailing contextual conditions (Lesthaeghe 1980; Coale and Watkins 1986). Beyond that, the change process itself can also be a source of spatial variation if characterized by diffusion through social interaction between individuals or between individuals and institutions. As social interaction is usually denser within countries or specific localities (Bongaarts and Watkins 1996), it can contribute to the temporal emergence of spatial hotspots of change during the transition process.

Perhaps the most prominent and most developed theoretical framework for explaining changes in family formation behavior during the past decades is the Second Demographic Transition (SDT) framework (Van de Kaa 1987; Lesthaeghe 2010). According to the SDT, structural, cultural, and technological factors are driving changing lifestyle choices (Van de Kaa 1994). Structural factors encompass the process of modernization, the extension of the welfare state, and the rise of higher education. Cultural factors comprise the process of secularization, the rise of individualistic values, and the growing importance of self-expression and self-fulfillment, while technological changes include the emergence of highly effective contraceptive methods (Van de Kaa 1994). Increasing female economic empowerment is also seen as an important driver for the emergence of new family behavior (Bumpass 1990, Lesthaeghe 2010), though this view is not undisputed (see, Oppenheimer 1994). From an economic viewpoint, traditional marriage arrangements were often characterized by trading situations where men and women specialized in different areas of life (Becker 1981). Female empowerment and 
gender equality are seen as factors that reduce the gains of marriage for women and consequently foster a rise in nonmarital cohabitation (Lesthaeghe 1995). It has also been argued that for dual-career couples cohabitation might be attractive as a prelude to marriage, as couples could use this period to negotiate the division of labor between them in order to explore the viability of a potential marriage (see, for example, Ono 2003).

The SDT has been criticized for not fully explaining the divergence in childbearing within cohabitation (Sobotka 2008; Perelli-Harris et al. 2010). Based on the theoretical considerations of the SDT, one might expect the highly educated to be at the forefront in adopting new behaviors such as childbearing within cohabitation, because they may hold more liberal values and may be more resistant to prevailing social stigmas. However, empirical research shows that many societies have a negative educational gradient of childbearing within cohabitation, where women with lower levels of education are more likely to have children within cohabitation compared to more highly educated women. Evidence of this has been provided for several European countries, (for example, Perelli-Harris et al. 2010) and the United States (for example, Upchurch, Lillard, and Panis 2002). For cohabitation independent of childbearing a negative educational gradient has also been found for a large number of Latin American countries (Esteve, Lesthaeghe and López-Gay 2012). Such findings have raised the notion that there may also be elements that explain new family behavior other than those considered by the SDT, or that the SDT is evolving along two different trajectories (Sobotka 2008). One such element is blocked opportunities, which may stem from economic constraints and economic uncertainty (Billy and Moore 1992; Oppenheimer 1994; Kiernan 2004; Perelli-Harris et al. 2010). Among disadvantaged groups or in large-scale economic crises there might emerge a "general milieu of social disorganization" (Billy and Moore 1992) whereby social norms prescribing the 'right' order of life-course events lose ground. In situations where individuals are faced with blocked opportunities and uncertainties, they may prefer cohabitation over marriage due to its lower level of commitment or they may decide to postpone marriage until they feel they have a clearer outlook on life (see also, Oppenheimer 1994; Kalmijn 2011). These mechanisms have been referred to as a "pattern of disadvantage" (Perelli-Harris et al. 2010).

Overall, it seems that the existing theoretical frameworks related to the recent increase in childbearing within cohabitation are not entirely coherent (see also, Kiernan 
2004; Sobotka 2008; Perelli-Harris et al. 2012). The main motivation of our paper is to contribute to overcoming these inconsistencies. We believe that they stem in part from a gap in knowledge about how the relevance of existing theories varies dependent on the scale at which variation in family formation behavior is occurring (for example, between individuals, subnational regions, and countries). Our approach is based on the assumption that, besides individual characteristics, prevailing social norms and economic conditions also play a role when couples decide whether or not to have a first child within cohabitation or within marriage (see, for example, Lesthaeghe 1980). This is also supported by the research findings of Liefbroer and Billari (2010), which show that social norms are still highly relevant for family behavior, even in societies that are characterized by very high degrees of individualization. In our analysis we consider social norms such as family values, secularism and female economic empowerment, next to structural economic conditions.

Given that many explanations for recent changes in family formation behavior point to contextual factors, few studies exist that investigate how social and economic conditions are associated with individual behavior in a multilevel framework. Exceptions include a study by Billy and Moore (1992) on non-marital fertility in the United States and one by Kalmijn (2013) on cohabitation during midlife in European countries. To the best of our knowledge, no large-scale cross-country studies have yet examined the role of social norms and economic conditions in shaping childbearing within cohabitation applying a multilevel framework, controlling both for the subnational regional and country-level dimension. The aim of this paper is to fill this research gap.

By analyzing harmonized survey data on family formation behavior from $16 \mathrm{Eu}-$ ropean countries, we estimate the probability of having a first child within cohabitation rather than within marriage. In the specification of our models we take into account the possibility that the relevance of existing theories may vary with regard to their ability to explain variation in our dependent variable at the individual level and at different levels of aggregation. Hence, we apply a three-level hierarchical model in which we nest individuals in their subnational region of residence which in turn is nested in the country of residence. This allows us to test the relevance of existing theoretical considerations by studying how between- and within-country variation in social norms and economic conditions is associated with spatial variation in childbearing within cohabitation and at the 
same time be able to control for individual-level characteristics. We believe that Europe is ideal for such a study because the countries on this continent display a great diversity in welfare state types (Esping-Andersen 1999; Esping-Andersen 2009), economic conditions, levels of secularization (Halman and Draulans 2006), and long-standing norms related to family formation behavior (see, for example, Hajnal 1965).

\section{Background}

When conceptualizing links between social and economic contexts on individual norms and decision-making, one has to note that they can occur at multiple social and geographic dimensions. They can operate in dyadic form between partners, in household and family contexts, or within neighborhoods or social networks of friends and coworkers. How nonmarital childbearing is perceived by the social context may influence the views of individuals on this behavior and their family formation decisions. At the municipality or regional dimension, structural factors such as general economic conditions or local policy programs (such as housing support to lone mothers) may have an effect on demographic decision-making. Family legislation may also vary across regions in some highly federated countries (see for example, González Beilfuss 2005 for Spain). The national level is highly relevant in a number of dimensions (Watkins 1991; Klüsener, Perelli-Harris, and Sánchez Gassen 2013). In most European countries, family legislation is harmonized at the national level (Perelli-Harris and Sánchez Gassen 2012). These regulations did at least historically often reflect social norms hold up by the dominant religious institutions (see also, Finke and Adamczyk 2008; Witte 2012). The existing legislation can set intentional as well as unintentional incentives to foster or discourage childbearing within cohabitation. Standardized education curricula and nationwide mass media are also likely to contribute to a harmonization of social norms in demographic behavior within countries (Watkins 1991). While some of the contextual conditions have a very explicit spatial dimension (such as households and nation states), others have such a dimension to a much lesser degree (social networks). In our study we focus on contexts with an explicit spatial dimension. This includes the nation states and the subnational regions. ${ }^{1}$

We consider four key social and economic dimensions: the social disapproval of cohabitation, the importance of religious norms, the economic autonomy of women, and 
economic conditions. The likeliness of individuals or couples to adopt new behavior which for a long time was perceived by many as norm-deviant may be highly dependent on the perceived prevailing norms in the social context in which these individuals are embedded (Lesthaeghe 1980; Liefbroer and Billari 2010). ${ }^{2}$ Both the dimension "Social disapproval of cohabitation" and "Importance of religious norms" deal with social norms that may influence the decision-making process of couples and the pace at which this new behavior is diffusing in a region. Historically, there is a strong link between religion and marriage. Since the late Middle Ages, the Catholic Church has held the Christian sacrament of marriage the sole base of intimate relationships and human reproduction (Coester 1993: 547; Venger 2004: 25). The Protestant reformers did little to change that view. ${ }^{3}$ Like the Catholic Church, also the Orthodox Church regarded marriage as a sacrament. ${ }^{4}$ Although marriage in most European countries is today solely a secular act, religious norms are still playing a role in influencing family formation behavior (Village, Williams, and Francis 2010; Kalmijn 2013). In particular, the (maledominated) Catholic Church still takes strong stances on premarital sexual intercourse and nonmarital cohabitation. There are also indications that the secularization process has substantially slowed down in a number of northwestern European countries, which were the forerunner in this trend. Evidence for this has been presented by Kaufmann, Goujon, and Skirbekk (2012), who show that even in these countries around 50 percent of the population still express religious beliefs. ${ }^{5}$

Research that looked into how religiosity relates to family formation behavior at the individual level found evidence for strong positive associations between measures of religious affiliation and/or levels of religious commitment and conservative sexual norms and behavior (see, among others, Thornton, Axinn, and Hill 1992; Katz 2001; Finke and Adamczyk 2008). Individuals with secularist attitudes, on the other hand, seem to be much more like to cohabit (Village, Williams, and Francis 2010) or to have a child within cohabitation (see, for example, Berghammer 2012). However, social disapproval of cohabitation is not just dependent on religiosity; we also find regions in Europe where the importance of religious norms is low yet disapproval of cohabitation is high (for example in eastern Europe). We therefore decided to cover both dimensions in our analysis. 
We believe that social disapproval of cohabitation may affect the decisionmaking process of couples along two dimensions. In a region where many people disagree with couples cohabiting, it is also more likely that one or both partners are of the opinion that men and women should be married if they live together and have children. Furthermore, they may also influence the behavior of individuals who are in principle open to cohabitation. If they are aware that cohabitation and childbearing within cohabitation is generally regarded as norm-deviating behavior in their region, they may decide to adopt norm-complying behavior and marry before the birth of the child. This can be linked theoretically to Bourdieu's concept of social capital, which defines social capital as "the sum of the resources, actual or virtual, that accrue to an individual or a group by virtue of possessing a durable network of more or less institutionalized relationships of mutual acquaintance and recognition" (Bordieu and Wacquant 1992: 119). People may fear that if their behavior deviates from existing norms, it might negatively affect their social capital. This could also have repercussions on their access to financial assets (disinheritance by parents, loss of job and career chances). Coale (1973) argues in a similar vein when he refers to "willingness" as one of his three preconditions for a transition process toward a new pattern of behavior gaining momentum in a society. Thus, regions with lower disapproval of cohabitation might witness faster diffusion processes compared to more conservative regions. It is also important to point out that we are looking at associations and not causalities, as lower levels of disapproval might also stem from a higher share of people having already adopted the new family formation behavior. We expect children to be less likely to be born within cohabitation than in marriage in social contexts where disapproval of such behavior is high.

Similarly, we believe that religious norms play a role in shaping family-related behaviors both at the individual and at the contextual level (Finke and Adamczyk 2008). We expect the mechanisms how these norms influence individual behavior to be very similar to the ones described for the social disapproval of cohabitation dimension. However, a difference is likely to exist in the way how these religious norms are uphold in space and time, as this might to a large degree depend on the ability of the dominant religious institutions to influence societal debates, social contexts and legislation. Many European countries have historically one dominating (national) religious institution, whose ability to influence societal developments and legislation varies across countries. 
This makes it likely that we see substantial cross-country variation in secularization tendencies both among individuals as well as in reforms of the family legislation (see also Finke and Adamczyk 2008). This might have effects on the between-country variation in cohabitation levels. Thus we expect the between-country dimension to be more relevant for religious norms compared to the social disapproval of cohabitation measure. Nevertheless, regional differences in religious norms might also exist within countries, for example between metropolitan and more rural areas. Overall, we expect people living in contexts where religious values remain widespread to be more likely to marry prior to conception or childbirth.

Regarding the dimension "Women's economic autonomy," we believe that perceptions of this aspect influence the decisions of couples with young children about how to divide gainful employment and child-rearing responsibilities between them. In an environment where the male breadwinner ideal is highly prevalent, women may be economically dependent on kin relations. On the other hand, in an environment where women and men have practically equal employment opportunities which are in addition supported by good access to institutional childcare, women may be less reliant on kin relations for supplying them and their offspring with necessary assets. As a result, marriage may lose its function as a female strategy to secure their livelihood while they are young mothers. We believe that the dimension of women's economic autonomy is closely linked with the evolution of the welfare state, which has reduced individuals' reliance on kinship networks and the church as providers of social security and assistance, also referred to as defamilisation or decommodification (McLaughlin and Glendinning 1994; Esping-Andersen 1999). The degree of defamilisation differs across states, as can be observed in the variation in instruments and levels of support for individuals and families (Esping-Andersen 1999; Perelli-Harris and Sánchez Gassen 2012). These state supports may have allowed women to become less reliant on the institution of marriage and instead more willing to have children outside marriage. Furthermore, the dimension of the degree to which states support or limit female employment differs considerably across countries. ${ }^{6}$ We expect children in regions where women's economic autonomy is higher to be more likely to be born within cohabitation than within marriage. Since theoretical considerations suggest that women's economic autonomy is linked to the evolution of the welfare state in a given country, we assume that this di- 
mension will be more relevant to understanding between-country variation than to understanding within-county variation.

The dimension "Structural economic condition" is introduced on the basis of theoretical considerations related to the pattern of disadvantage, where it is argued that social disorganization and the prevalence of a "culture of poverty" or blocked opportunities may serve to increase the risk of having children outside marriage/within cohabitation (Billy and Moore 1992; Perelli-Harris et al. 2010). In recent decades, some aspects of life in Europe, such as the employment and housing markets, have become more uncertain, leading to postponement of family-related events such as leaving the parental home, marrying, and childbearing (Kohler, Billari, and Ortega 2002; Mills and Blossfeld 2013; Vignoli, Rinesi, and Mussino 2013). These trends of rising uncertainties has being linked to processes of globalization including increased global competition (for example, Mills and Blossfeld 2013). Evidence for effects of employment uncertainty on union formation decisions of men has been provided by Kalmijn (2011) based on panel data for 13 European countries. ${ }^{7}$

As it is usually those with the lowest level of education that are most affected by economic uncertainty, Perelli-Harris et al. (2010) argue that those with higher education may be more likely to marry and to have children within marriage (see also, Kalmijn 2011). This pattern of disadvantage argumentation does not seem to fit into the core theoretical framework of the SDT. However, in this respect it might be relevant to consider whether marriage with a man with lower education and an uncertain employment outlook may offer few gains to a woman with lower education, both materially and symbolically (see also, Esping-Andersen and Billari 2012). This is particularly true in contexts with small gender differences in employment opportunities and good access to institutional childcare, both of which provide women with economic independence. Evidence of this was presented by Konietzka and Kreyenfeld (2002) in a study on East Germany. Thus, processes which are linked to the SDT may also contribute to a negative educational or social status gradient in childbearing within cohabitation. Overall, we expect that children are more likely to be born within cohabitation than in marriage in regions and countries with unfavorable economic conditions. 


\section{Data}

For our study, we use harmonized individual-level survey data on union formation and fertility behavior for 16 countries across Europe. In our analysis, we look at births which occurred in the period between 2000 and 2007, as this is the time period for which we could obtain contextual data at the regional level for all countries. The survey data is made available by the Harmonized Histories Project (see www.nonmarital.org) (Perelli-Harris, Kreyenfeld, and Kubisch 2010). For twelve countries the data originates from the Generations and Gender Programme (GGP), which conducts national panel surveys with a focus on family formation behavior. These countries are: Austria, Belgium, Bulgaria, Estonia, France, Germany ${ }^{8}$, Hungary, Italy, Lithuania, Norway, Romania, and Russia. For the Netherlands, the data comes from the Family and Fertility Survey (FFS), which complies closely with the Generations and Gender Surveys (GGS) since the FFS served in part as a blueprint for developing the GGS questionnaire. For Poland, we used the Employment, Family and Education Survey, while for Spain and the United Kingdom the Harmonized Histories datasets have been built up from data from the Spanish Survey of Fertility and Values and the British Household Panel Survey. Unfortunately, not all of the available national surveys cover both men and women. We therefore decided to include only female respondents in our sample.

The contextual value data on social norms and values were derived from the following surveys: European Social Survey (Waves 1 to 4, collected biennially between 2002 and 2008); European Value Survey (Wave 3 from 1999, Wave 4 from 2008); and Generations and Gender Survey (Wave 1 collected between 2001 and 2010). The fact that there is a large overlap in the value questions posed in these three surveys allows us to pool together the data from these surveys in order to increase the number of responses available at the subnational regional level. When extracting the value data, we applied design weights, wherever available. Unemployment data are derived from aggregated information from the EU-SILC surveys as provided in the GGP Contextual Database (GGP-CDB 2012).

Our data permit us to include prevailing social norms and economic conditions at the contextual, regional, and national levels in our analysis, though we are unable to control for these attitudes and the labor market status at the individual level. The latter would have allowed us to examine the relationship between individual-level characteris- 
tics and contextual conditions (such as the behavior of secularized persons living in religious social contexts). Nor do we have information on attitudes of partners, close family members or other social contacts. ${ }^{9}$ The lack of information on individual-level attitudes poses limitations for interpreting our findings, as we are unable to determine whether contextual-level associations at the regional and national levels stem from differences in compositional characteristics or from contextual influences. However, this distinction is difficult to make in any case because, for example, individual-level attitudes are likely to be shaped by the context in which people have been socialized (Bronfenbrenner and Morris 2006). This regional context remains the same for the majority of Europeans throughout their lives, since the proportion that migrates to other subnational macro-regions is usually small (GGS, IPUMS, own calculations).

In spatial terms, we define context as the region (or small country) in which an individual has his or her place of residence. In doing so, we had to decide which method of regional division to use for the countries in our analysis. This decision may have farreaching implications because outcomes may differ depending on the level of aggregation at which contextual conditions are introduced in the model. This issue is also referred to as the modifiable areal unit problem (Openshaw 1984), one of the central challenges in spatial analysis. The European Union offers the NUTS classification system, which aims to divide Europe at different geographic hierarchies (NUTS 1 to NUTS 3) in regions with comparable population size. However, this system of classification has its limitations: it is neither clear-cut ${ }^{10}$ nor does it necessarily reflect long-standing administrative definitions within countries. For example, in Germany, Bundesländer (states) represent the most relevant subnational administrative units and are classified at the NUTS 1 level, whereas in Austria, the Austrian Bundesländer as the most relevant subnational administrative unit are classified at the NUTS 2 level. Besides, our analysis is constrained by the subnational regional divisions for which we have survey and contextual data available. In general we used regional divisions at the NUTS 1 level (Belgium, Estonia, France, Germany, Italy, Lithuania, Spain, and United Kingdom). Where the data allowed and where a more detailed division better reflected long-standing administrative definitions, we used the NUTS 2 level (Austria, Bulgaria, Hungary, Norway, Poland, and Romania). In the case of the Netherlands we had to use the national level because the survey data did not provide information on region of residence. How- 
ever, since the population size and area of the Netherlands are comparable to other regions in our sample (for example, the bordering NUTS 1 region of North RhineWestphalia in Germany), we do not consider this a problem. For Russia, which does not use the NUTS classification system, we used the level of the economic regions, which in terms of population size are approximately comparable to the NUTS 1 regions. In total, we distinguished between 116 subnational regions and small countries in our study (see Appendices 1 and 2 for details).

\section{Methods}

For the analysis, we employ a multilevel logistic regression model with random intercept. The motivation for this choice is that both our hypotheses and our data are hierarchically structured (individuals nested in regions nested in countries). The logistic link function is used as we treat our dependent variable, childbearing within cohabitation vs. marriage, as dichotomous (Agresti 2002). Multilevel models allow us to detect the effect of the context on individual behavior as well as to identify the macro characteristics mainly associated with individual-level outcome variation across contexts. In these models the clustering of observations is seen as an intrinsic characteristic of the population and is explicitly considered in the analysis.

In particular, we apply a three-level hierarchical model consisting of individuals nested in 116 regions, nested in 16 countries. The literature focusing on how many countries should be used in a multilevel framework gives varying rules of thumb, ranging from just eight or ten to 30, 50 or even 100 groups (see, Bryan and Jenkins 2013; Stegmueller 2013 for an overview). Simulations performed by Stegmueller (2013) support our research design, as his results for a multilevel (probit) model suggest that 15 countries is the cut-off point under which standard errors become too biased. In addition, a positive aspect of our dataset is that it comprises countries from all parts of Europe with no area above proportion being represented (we cover, for example, just one Scandinavian country, one from the British Isles and one from the Iberian Peninsula).

We follow an empirical strategy consisting of three steps. First, we estimated the so-called null model (which does not include any contextual or individual-level covariates) to test whether our data do or do not require a multilevel analysis. Second, we run 
a model with first-level, i.e. individual-level, variables only so as to better see in which direction, and, if significant, how strongly, they act. Our individual-level control variables include the mother's age in five-year age groups at the time of childbirth, educational attainment at the time of interview, and social background of the parents, measured in educational attainment. Finally, we estimate a larger model, including both first-, second- and third-level variables (at the individual, subnational, regional, and country levels) in order to interpret variability associated with these spatial dimensions. A comparison between the different model specifications is made through the intra-class correlation coefficient (ICC), which expresses how much of the total unexplained variation in childbearing within cohabitation is due to the regional and the national level. The ICC was computed following standard practice (Snijders and Bosker 1999).

It may be problematic to use absolute values both at the between- and withincountry level when controlling for social norms and economic conditions due to concerns about the nation states being "black boxes" of complex auto-organization (Decroly and Grasland 1993) for which our covariates may only to a limited degree be able to control for. For example, we are unable to include variables reflecting differences in the welfare state setups and the historical development of family legislation. Nor do we have information on national educational curricula or national mass media discussions, which are likely to influence norms related to family formation behavior that may contribute to between-country differences in demographic outcomes. In addition, the contextual influences of a region with relatively high unemployment in a European country with a relatively low unemployment level may have a different impact on the demographic decisions of its residents than those of a region with similar levels but which is situated in a country with relatively high unemployment. In order to deal with this issue we do not use the absolute levels for the within-country contextual dimension. Instead, we employ a relative measure indicating to which degree the region deviates from the country mean. As a result, we add two variables for each of our contextual dimensions. Our "between-country" measure is using absolute national-level average values to measure the association between childbearing within cohabitation and variance in our covariates between countries. For our "within-country" measure we take the subnational regional values and subtract from them the average national-level values ${ }^{11}$ in order to derive the relative difference from the national average. 


\section{Choice of covariates on social norms and economic conditions}

We will now present the motivation for the choice of variables to capture our four key contextual dimensions. To measure "social disapproval of cohabitation" we use a variable containing information on whether people think it acceptable for couples to live together without being married. From the responses we constructed an index from 1 (low disapproval) to 5 (high disapproval). As shown in Table 1, the highest levels of disapproval are mostly concentrated in central and eastern European countries such as Lithuania, Poland, Romania, and Russia. Italy also records high values of disapproval of cohabitation. Within western Europe, on the other hand, variation in this item is rather low. Moreover, there are quite a number of countries with substantial subnational regional variation in this measure (such as Belgium, Italy, and Romania). This lends support to our approach to model contextual effects at the regional level rather than at the national one alone. The overall variation across the regions in our sample is also quite substantial (1.7-3.5).

Table 1: Descriptive Statistics (Mean, Min, Max, Std. Dev.) of the Contextual-level Measures Included in the Model

\begin{tabular}{|c|c|c|c|c|}
\hline $\begin{array}{l}\text { Country (share of } \\
\text { first births in co- } \\
\text { habitation) }\end{array}$ & $\begin{array}{c}\text { "Social disapprov- } \\
\text { al of cohabitation" } \\
\text { (Index } 1 \text { (low): } 5 \\
\text { high)) }\end{array}$ & $\begin{array}{l}\text { "Importance of } \\
\text { religious norms" } \\
\text { (Index } 1 \text { (low): } \\
10 \text { (high)) }\end{array}$ & $\begin{array}{c}\text { "Women's eco- } \\
\text { nomic autonomy" } \\
\text { (Index } 1 \text { (low): } 5 \\
\text { (high)) }\end{array}$ & $\begin{array}{c}\text { "Structural economic } \\
\text { conditions" } \\
\text { (Adult Unemployment } \\
\text { Rate) }\end{array}$ \\
\hline Estonia (61.2) & 2.5 & 3.6 & 3.6 & 8.7 \\
\hline Norway (59.0) & $2.0(1.8,2.3,0.16)$ & $3.9(3.6,4.5,0.29)$ & $4.2(4.1,4.4,0.08)$ & $3.0(2.6,3.3,0.2)$ \\
\hline France (53.3) & $1.9(1.9,2.1,0.09)$ & $3.7(3.3,4.3,0.29)$ & $3.9(3.5,4.1,0.20)$ & $7.7(6.1,9.8,1.4)$ \\
\hline Austria (47.2) & $2.1(2.0,2.2,0.07)$ & $5.1(4.8,5.6,0.25)$ & $3.6(3.5,3.7,0.08)$ & $3.9(1.9,7.1,1.5)$ \\
\hline $\begin{array}{l}\text { United Kingdom } \\
(44.8)\end{array}$ & $2.5(2.3,2.8,0.15)$ & $4.2(3.9,5.5,0.47)$ & $3.7(3.5,3.8,0.10)$ & $3.6(2.4,5.5,0.9)$ \\
\hline Belgium (42.6) & $2.1(2.0,2.4,0.23)$ & $4.9(4.8,4.9,0.06)$ & $3.6(3.4,3.7,0.12)$ & $6.7(4.5,13.8,4.7)$ \\
\hline $\begin{array}{l}\text { The Netherlands } \\
\text { (31.7) }\end{array}$ & 1.7 & 5.0 & 3.8 & 3.1 \\
\hline Bulgaria (30.7) & $2.3(2.3,2.5,0.08)$ & $4.3(3.7,4.6,0.36)$ & $3.2(3.0,3.3,0.13)$ & $12.2(9.7,18.6,3.2)$ \\
\hline Germany (29.2) & $2.2(1.9,2.5,0.13)$ & $4.3(2.3,5.0,1.05)$ & $3.6(3.3,4.0,0.19)$ & $9.6(5.5,20.6,5.6)$ \\
\hline Spain (27.1) & $2.1(2.0,2.3,0.12)$ & $4.5(4.3,4.8,0.24)$ & $3.7(3.2,4.0,0.25)$ & $9.9(6.2,15.3,3.0)$ \\
\hline Hungary (22.8) & $2.4(2.3,2.4,0.04)$ & $4.3(3.7,5.2,0.50)$ & $2.7(2.6,2.9,0.11)$ & $5.0(3.4,8.5,1.8)$ \\
\hline Russia (20.7) & $2.8(2.7,3.0,0.12)$ & $4.3(3.1,4.9,0.55)$ & $3.0(2.9,3.2,0.10)$ & $7.9(4.3,12.5,2.4)$ \\
\hline Lithuania (18.2) & 2.8 & 5.5 & 3.1 & 11.1 \\
\hline Romania (14.7) & $3.2(2.9,3.5,0.18)$ & $6.8(6.4,7.1,0.22)$ & $3.1(3.0,3.3,0.10)$ & $5.4(4.5,7.0,0.9)$ \\
\hline Poland (8.5) & $2.7(2.5,2.9,0.12)$ & $6.6(6.0,7.3,0.36)$ & $3.1(2.8,3.5,0.14)$ & $16.3(12.9,23.0,3.2)$ \\
\hline Italy (2.1) & $2.9(2.6,3.2,0.26)$ & $6.0(5.5,6.7,0.46)$ & $2.8(2.3,3.0,0.29)$ & $6.8(2.7,15.4,6.0)$ \\
\hline
\end{tabular}

Note: Countries are listed in descending order according to the share of first births in cohabitation vs. marriage registered in our sample.

Source: Contextual Information derived from European Social Survey, European Value Survey, and Generation and Gender Survey (for more details see Appendix 3) 
However, as we are mainly interested in childbearing within cohabitation and not whether unmarried people live together, there is a chance that attitudes toward these two behaviors may not cohere. People may think it is acceptable for couples to live together without being married as long as they marry once they become parents, which would mean that while cohabitation per se may be social acceptable, childbearing within cohabitation was not. Our data contain no information for all countries on attitudes toward social disapproval of nonmarital childbearing. In order to test whether the two variables would measure the same underlying social norm, we contrasted the responses to the two questions in countries for which data are available (see Appendix 3A). The overall picture is that (with a few exceptions) there is coherence between the two indicators, which justifies our choice to use disapproval of cohabitation as a measure.

In order to capture "importance of religious norms" we use a question posed in the European Social Survey asking people how important religion is for them in life. The measure is constructed as an index from 0 (not important) to 10 (very important). Compared to using a measure based on religious denomination, this indicator seems particularly better suited to capturing variation in those countries where only a small proportion of the population has no denomination (see Appendix 3B). In this variable we also see substantial variation across countries, with Estonia, France, and Norway scoring values below 4 while the highest values registered in Romania and Poland are above 6.5. Again we find substantial variation within countries. This includes Germany, where the eastern regions record extremely low religiosity scores (far below 3). Other countries with substantial variation include Italy, Russia, and the United Kingdom. ${ }^{12}$

For the dimension "women's economic autonomy" we use a value question which measures the extent to which the male breadwinner model is still dominant in a society. Here respondents were asked whether they agree or disagree that men should be given preference when available jobs are scarce. Out of the responses to this question we again construct an index ranging from 1 (low disagreement) to 5 (high disagreement). We believe that this measure is the best one for our model as it captures existing social norms about female economic autonomy. Alternatively, we could have used the female employment rate, but we decided against this because female employment levels are also influenced by the overall economic conditions in a region. In order to test the coherence between the two variables for our contextual regions, we plotted the variables 
as shown in Appendix 3C. The plot demonstrates that the variables are highly associated in most regions covered in our analysis. Strong negative deviations from a linear association are mostly recorded by regions in eastern Europe (Lithuania and regions in Hungary, Poland, and Russia), where the relatively high female employment rate might be a legacy of the communist era. Deviations in the opposite direction are registered in Belgium, Spain, parts of France, and Northern Ireland. This may be related to the job market generally not performing well or failing to catch up with changing views about giving male jobseekers priority in the labor market. Our chosen measure also shows considerable variation across countries and regions. Scores below 3 are recorded in Hungary and Italy, while the highest scores for disagreement are reported in countries as diverse as Norway, France, the Netherlands, and Spain. Countries with high internal regional variation include Italy and Spain.

For our contextual dimension on "structural economic conditions" we use unemployment rates as our indicator. We use the values for 2003, which is the only year for which data for all regions are available. This year is approximately in the middle of the period from which we derived our births within cohabitation and marriage (2000 and 2007). Because we do not include births that were conceived after the onset of the current global economic crisis (which started in the second half of 2008), we believe that the values for 2003 are quite representative for our study period.

Among the unemployment indicators our choice fell on the rate for all adults (25-64 years) (GGP-CDB, derived from EU-SILC surveys). Alternatively, we could have used youth unemployment rates (15-24 years), which might be considered preferable since nonmarital childbearing mostly occurs at a young age. However, in order for a culture of anomie to emerge, we believe it is necessary that unemployment levels be generally high. Thus, the use of adult unemployment rates is more appropriate for our models. A scatter plot of these two variables is displayed in Appendix 3D, which demonstrates that these two indicators are highly correlated. The only stark outliers are the regions in eastern Germany, where in 2003 youth unemployment was rather low compared to adult unemployment. Regarding the variation, we see adult unemployment levels at the national level vary from values below 4 percent in the Netherlands, Norway, and Austria to values above 16 percent in Poland. Countries with substantial internal variation include Belgium, Germany, and Italy. 


\section{Results}

As illustrated in Figure 1, childbearing within cohabitation in Europe shows quite extensive regional variation. The map shows our dependent variable as derived from the survey data. For the period 2000 to 2007 it shows the share of first births among partners sharing a household which occur within cohabitation and not within marriage. Italy registered an average of just 2 percent of first births within cohabitation, while the highest levels were recorded in Estonia (61 percent) and Norway (59 percent). Levels below 5 percent were also registered in many Polish and Romanian regions. Countries with high regional variation include Germany, Norway, Poland, and Russia. Overall, however, the between-country component of variation seems to be more relevant than the within-country component (see also below). France and Italy, for example, exhibit little internal variation, while there is a clear divide in levels across the French-Italian border. The same is true for Austria and western Germany.

Figure 1: Regional Variation in Childbearing in Cohabitation (First Births 2000-2007)

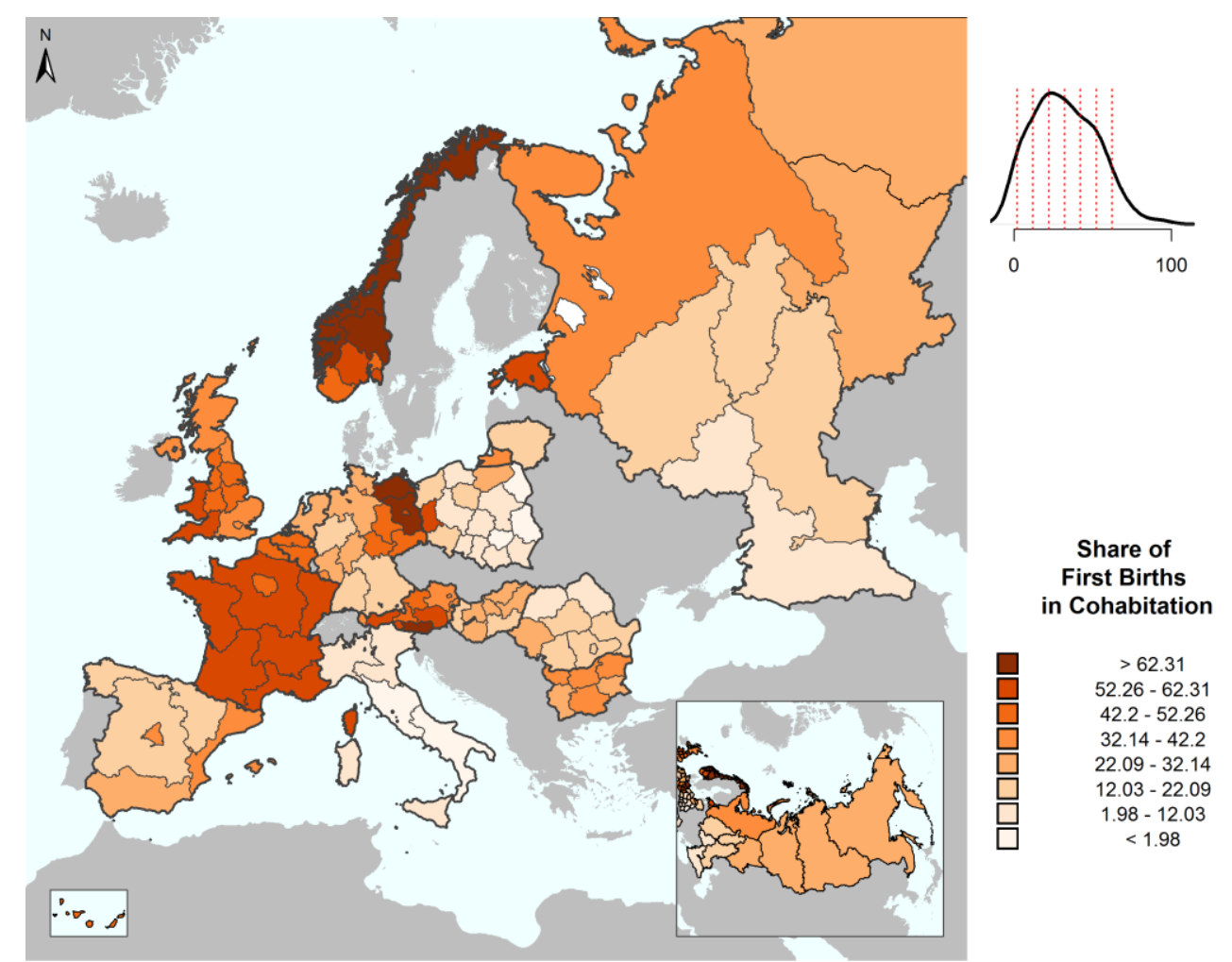

Note: The map is based on a standard deviation categorization centered on the mean (mean: 32.14, standard deviation: 20.11). The histogram shows the density curve and the cut points of the chosen categories.

Source: Harmonized Histories, own calculations

Base Map: MPIDR and CGG; partly based on (c) Eurogeographics for the administrative boundaries. 
Before presenting our model results we first investigate how much variation in our dependent variable can be attributed to variation in our contextual dimensions in the different models. We then look into the associations between our contextual variables and the propensity to have a first child within cohabitation. Figure 2 illustrates that in model 1 - the unconditional (null) model -27.6 percent of the total unexplained variation in the timing of a first birth (within cohabitation or within marriage) can be attributed to between- or within-country variation across our 116 regions. Betweencounty variation clearly dominates with 23.4 percentage points related to differences between countries, while only 4.3 percentage points can be linked to within-country variation. This suggests that the country level is far more relevant to understanding variation in childbearing within cohabitation and marriage compared to the regional level. However, it is important to note that these numbers may to some degree be influenced by the level of regional detail at which we chose to conduct the analysis.

\section{Figure 2: Regional Variation in Childbearing in Cohabitation}

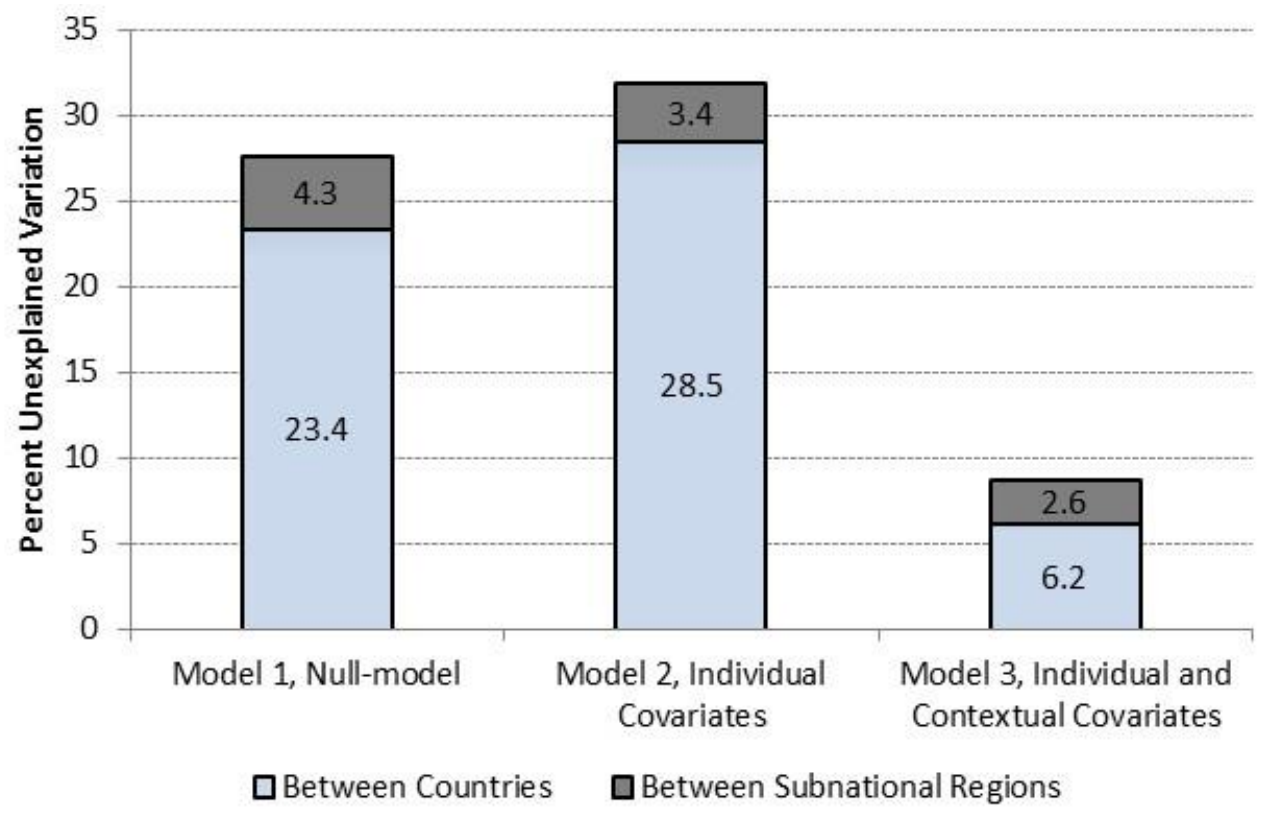

Note: The figure displays the intra-class correlation of the three models; namely how much of the total unexplained variation in fertility in cohabitation is due to the regional context.

Source: Harmonized Histories, own calculations

When we control our estimates for individual characteristics in Model 2, the unexplained variation that can be attributed to the context increases to 32 percent. But 
after controlling for regional-level covariates in Model 3, only 8.6 percent of the unexplained variation can still be linked to the context. These results suggest that the contextual-level variables we selected can account for a very large proportion of the betweenand within-country spatial variation in whether a first birth occurs within cohabitation or within marriage. To be sure that the share of explained variation was not accounted for by one variable alone, we ran Model 3 separately for each contextual-level variable. ${ }^{13}$ The results show that, when considered in isolation, none of the contextual-level variables has a dominating effect. It seems that the most important variable is "women's economic autonomy" and the least important variable is "structural economic conditions", while the other two are found somewhere in between. We also ran a model with all contextual-level covariates apart from "disapproval of cohabitation" to obtain additional proof that the effect of this variable does not prevail on the other variables. The results show that the overall contextual variation decreases to 11.3 percent and that when the "disapproval of cohabitation" variable is added it decreases further to 8.6 percent. These tests suggest that all selected contextual variables contribute to understanding variation in childbearing within cohabitation with none having a dominating effect.

Table 2 shows the results for the individual-level and contextual variables. As the individual-level variables are not the prime focus of this paper, we only comment on them briefly. Regarding age, the variables show the common pattern that childbearing within cohabitation is more likely to occur among young women and women aged over 40 years. For educational attainment, the educational gradient is negative in our European-wide sample, which is in line with the findings of Perelli-Harris et al. (2010) in their in-depth study of the relationship between educational attainment and childbearing within cohabitation. The social background items were not significant. It is relevant to note that the coefficients and significance levels of the individual-level covariates are very similar in Model 2, which only includes these covariates, compared to Model 3, which in addition contains the controls on social norms and economic conditions.

When we turn to results for the contextual variables (Model 3), we found the within-country variation for the dimension "disapproval of cohabitation" to be significantly related to variation in childbearing within cohabitation, while this is not the case for between-country variation. The within-country association is in the (expected) negative direction, which implies that subnational regions reporting higher levels of social 
disapproval of cohabitation compared to the national average show lower levels of childbearing within cohabitation. This could be interpreted in light of a social imitation/social capital mechanism among people living in the same region which may contribute to a strong interrelationship between social approval of cohabitation and likelihood of childbearing within cohabitation.

Table 2: Associations between Contextual Variables and Childbearing in Cohabitation Model 3 (Odds Ratios)

\begin{tabular}{|c|c|c|c|}
\hline & $\begin{array}{l}\text { Model 1 } \\
\text { Null-Model }\end{array}$ & $\begin{array}{l}\text { Model } 2 \\
\text { Individual } \\
\text { Covariates }\end{array}$ & $\begin{array}{l}\text { Model } 3 \\
\text { Individual and } \\
\text { Contextual Co- } \\
\text { variates }^{+}\end{array}$ \\
\hline \multicolumn{4}{|l|}{ Age at first birth } \\
\hline $15-19$ & & $2.95^{\star * *}$ & $2.95^{\star * *}$ \\
\hline $20-24$ & & 1 & 1 \\
\hline $25-29$ & & $0.56^{\star * *}$ & $0.55^{\star * *}$ \\
\hline $30-34$ & & $0.54^{\star * *}$ & $0.53^{* * *}$ \\
\hline $35-39$ & & $0.76^{*}$ & 0.74 \\
\hline $40+$ & & 0.74 & 0.70 \\
\hline \multicolumn{4}{|l|}{ Educational level } \\
\hline High & & $0.48^{\star * *}$ & $0.49^{\star \star *}$ \\
\hline Medium & & $0.68^{* * *}$ & $0.68^{* * *}$ \\
\hline Low & & 1 & 1 \\
\hline \multicolumn{4}{|c|}{ Social background (father's highest education) } \\
\hline High & & 0.91 & 0.88 \\
\hline Medium & & 1.02 & 1.01 \\
\hline Low & & 1 & 1 \\
\hline \multicolumn{4}{|l|}{ Level 2 region } \\
\hline Intra-class Correlation & 4.27 & 3.35 & 2.58 \\
\hline \multicolumn{4}{|l|}{ Level 3 country } \\
\hline Intra-class Correlation & 23.38 & 28.48 & 6.17 \\
\hline \multicolumn{4}{|l|}{ Between-Country (Country Mean) } \\
\hline "Social disapproval of cohabitation" & & & 0.96 \\
\hline "Importance of religious norms" & & & $0.61^{* *}$ \\
\hline "Women's economic autonomy" & & & $5.81^{* * *}$ \\
\hline "Structural economic conditions" & & & 0.96 \\
\hline \multicolumn{4}{|c|}{ Within-Country (Deviation from Country } \\
\hline \multicolumn{4}{|l|}{ Mean) } \\
\hline "Social disapproval of cohabitation" & & & $0.20^{\star * *}$ \\
\hline "Importance of religious norms" & & & $0.72^{*}$ \\
\hline "Women's economic autonomy" & & & 0.95 \\
\hline "Structural economic conditions" & & & $1.04^{*}$ \\
\hline
\end{tabular}

Note: Social disapproval of cohabitation is measured as an index between 1 (low) and 5 (high); Importance of religious norms is measured as an index between 1 (low) and 10 (high); Women's economic autonomy is measured as an index between 1 (low) and 5 (high); and Structural economic conditions is measured as unemployment rate for men and women aged $25-64$ years. ${ }^{*} p<0.1{ }^{*} p<.05^{* *} p<.01{ }^{* * *} p<.001$.

Source: Harmonized Histories, own calculations 
Our religiosity variable is in line with our theoretical considerations significant in both the between-country and the within-country dimension. The coefficients are in the expected direction, which is that in regions and countries where religious norms are assigned lower importance, higher proportions of childbearing within cohabitation are recorded. This lends support to SDT considerations that assign secularization a prominent role in recent changes in family formation behavior.

The dimension "women's economic autonomy" is more salient at the betweencountry level than at the within-country level. That is, the stronger the disagreement in a country over men being given priority in the labor market if jobs are scarce, the greater the likelihood of couples having their first child within cohabitation. These outcomes are in line with our expectation that the economic autonomy of women is closely linked with the evolution of the specific welfare state context in which the individuals are embedded (see also, Esping-Andersen 2009). Our findings also support considerations as part of the SDT framework which link the increase in childbearing within cohabitation to processes of individualization and increasing (economic) autonomy of women.

Regarding the dimension "structural economic conditions", we found that the higher the regional unemployment level compared to the country mean, the higher the likelihood of childbearing within cohabitation. No significant coefficients were obtained for the between-country variable. As to why unemployment levels do not show up at the between-country dimension, one potential mechanism may be an interaction effect with social disapproval of childbearing within cohabitation. Such disapproval is very high in countries in Central and Eastern Europe, where levels of unemployment are highest. However, when testing for this we do not find any significant interaction effect between the two indicators.

In general, national unemployment rates mask substantial within-country (regional) differences. Economic affluence tends to be more concentrated in some areas than in others, and so do unemployment, infrastructures, technology, high-level occupations, and so forth. This lends support to considerations related to blocked opportunities contributing to a risk of childbirth within cohabitation (Billy and Moore 1992; PerelliHarris et al. 2010). 


\section{Discussion and conclusion}

Our model results show that, across Europe, both between-country and within-country variation in social norms and economic conditions are relevant for understanding spatial variation in the decision by couples to have the first birth within cohabitation or within marriage. The outcomes for the strong relevance of the between-country dimension confirm earlier findings of Klüsener Perelli-Harris, and Sánchez Gassen (2013), who analyzed aggregated regional-level data on nonmarital childbearing (see also, Watkins 1991 for research on earlier periods). Nation states still seem to play an important role in shaping demographic behavior, as for example national family legislation, standardized education systems and nationwide mass media are working towards harmonizing norms related to family formation decisions.

In our analysis we introduced four different variables related to social norms and economic conditions that reflect different theoretical dimensions of understanding recent changes in family behavior. Several outcomes lend support to considerations related to the SDT framework (Lesthaeghe 2010). These include the role of secularization, where at both the between-country and the within-county level we find a negative association between the degree of religiosity and the decision to have a child within cohabitation. The outcomes for the variable measuring disapproval of cohabitation and women's economic position also support expectations based on SDT considerations. However, disapproval of cohabitation is only relevant to understanding within-country variation, while women's economic position is only of importance for variation between countries. One interpretation of the outcomes for the social disapproval variable is that social norms governing cohabitation may instead evolve from local acceptance of lifestyle choices. On the other hand, the outcome for the women's autonomy variable is in line with our expectations based on welfare state research, where it is argued that variation in welfare states has a strong effect on how female economic positions are shaped (Esping-Andersen 2009).

Structural economic conditions also seem to be related to childbearing within cohabitation, though only at the within-country level. That is, there is a positive association between unemployment rates at regional level and childbearing within cohabitation; a finding which, at least at first glance, does not fit with the SDT framework, though it does fit the pattern of disadvantage argument (Billy and Moore 1992; Perelli- 
Harris et al. 2010) that individuals with blocked opportunities and/or living in disadvantaged regions are more likely to have a child within cohabitation. However, to some degree this pattern may also be related to the economic position of women compared to that of their partners, which would be consistent with SDT considerations. We already mentioned above that, in low-income classes and disadvantaged areas, men may only to a limited degree have better access to resources than do their female partners. For example, social assistance for men is rarely higher than for women. Thus, the economic and symbolic gains of marriage may be particularly low for women in disadvantaged social classes and regions, leading to a higher level of childbearing within cohabitation. If these mechanisms are of relevance, they would indicate that proponents of the SDT are perhaps overly stressing aspects of changing values. Maybe, economic processes at the couple level are driving the increases in cohabitation to a much higher degree, than hypothesized by the SDT.

In order to shed some light on these issues we ran separate models by educational attainment. However, the outcomes support our consideration that adverse economic conditions are of particular relevance for individuals from low economic backgrounds to a limited degree only. In the separate models by primary, secondary, and tertiary educational background, none of the unemployment variables is significant. If we pool women with primary and secondary educational background in one model, we receive a significant outcome for the within-country unemployment variable. However, the resulting odds ratio of 1.04 does not deviate from the one observed for the model in which all women are included (see Table 2). One reason for these outcomes might be that data availability constraints force us to focus on women in our analysis, while it has theoretically been argued that uncertainty effects occur particularly among disadvantaged men (Oppenheimer 1994; Kalmijn 2011). Thus, patterns might come out more clearly if this analysis would be carried out for men.

Our conclusion would not be valid without discussion of its limitations. We already mentioned that the data used do not allow us to control for social norms or labor market status at the individual level. Thus we cannot determine whether these associations are the effect of compositional characteristics or of contextual influences. However, this does not affect the validity of our findings in terms of whether variation childbearing within cohabitation across Europe is associated with variation in social 
norms and economic conditions. Another limitation is that our study uses a crosssectional approach. The model outcomes may have differed if we had used a longitudinal approach instead. For example, the rise in unemployment in eastern European countries parallel to increases in childbearing within cohabitation after 1990 might have returned a significant between-country effect of structural economic conditions in a longitudinal design.

Other dimensions with relevance for our models were tested but were omitted in the final results due to non-significant outcomes. These include a variable for general trust in the society, which was motivated by the fact that in most of the observed countries the legal implications of childbearing within cohabitation are still very different to those of childbearing within marriage (Perelli-Harris and Sánchez Gassen 2012). In general, cohabiting partners have fewer legal means available to secure their rights and instead have to rely on mutual trust that, should the relationship end, they will reach an arrangement that is acceptable to both parties and that does not harm the well-being of the child. One assumption would be that people in high-trust societies are more likely to trust their partner and thereby have a child within cohabitation than are people in lowtrust societies, where they may prefer marriage due to its legally binding arrangement. However, the models we tested for this variable did not deliver meaningful results, so we decided to omit it.

Another factor we considered was the dimension of the value of marriage and whether marriage is an outdated institution. However, including such a dimension might create multicollinearity between attitudes towards this and the decision of whether or not to marry prior to childbirth. Also, as more people cohabit and postpone marriage, marriage may become highly valued and only something people choose if they are sure they have found the right partner. The interpretation between the two might vary across time and space, thus making the variable difficult to interpret.

With regard to general implications, we believe that our study results may contribute to improving not only our understanding of variation in childbearing within cohabitation but also trends in the association between nonmarital childbearing and fertility levels across Europe. The national-level relationship between the two measures had been negative until the 1980s but since then has become positive (Billari 2005). This implies that countries with high levels of non-marital childbearing are also countries 
with relatively high levels of fertility. The driving force of this phenomenon may have been policies to reconcile family and working life, such as investments in child care, as it is likely that societies striving for greater economic autonomy for women may have moved early in that direction. There is growing evidence that policies to reconcile family and working life are playing a crucial role in understanding fertility variation across Europe (Thevenon and Luci 2012; Klüsener, Neels, and Kreyenfeld 2013). These policies are also likely to have affected marriage decisions, as they made women economically less reliant on their male partners and more open to having a child within cohabitation. We conclude that in order to understand variation in childbearing within cohabitation across Europe it is necessary to consider both variation in individual-level characteristics and variation in contextual conditions at different geographic scales. The fact that we find both between-country and within-country variation to be relevant suggests that couples' family formation decisions are associated with variation in social norms and economic conditions, both in regional settings and at the national level. In addition, our results indicate that the apparent inconsistency in existing theoretical considerations may arise because their importance varies according to the geographic scale at which variation is occurring. Some dimensions of the Second Demographic Transition framework, such as female economic autonomy, seem to be particularly relevant to understanding between-country variation in childbearing within cohabitation, while hypotheses related to a pattern of disadvantage seem more important to understanding variation between individuals and across subregions of countries. This may also explain why the discussion in North America leans more towards the pattern of disadvantage argument, as the empirical evidence is mostly derived from single-country studies. ${ }^{14}$ The European discussion, on the other hand, is to a large degree based on evidence from comparative studies, which may explain why the European debate leans more towards the Second Demographic Transition hypothesis. 


\section{Notes}

The maps used in this publication are partly based on the following source:

(c) EuroGeographics for the administrative boundaries.

1 Data restrictions prevent us from examining variation at the local municipal level.

2 Though Liefbroer and Billari (2010: 299) also stress that the effect of social norms might vary dependent on individual-level characteristics such as educational attainment.

3 Luther stated that marriage was a secular issue, though he still viewed marriage as the basis for human reproduction (Buitendag 2008). Calvin wrote that God "has also sanctified [the institution of marriage]. Hence, it is evident, that any mode of cohabitation different from marriage is cursed in his sight" (Calvin, 1845: 472).

4 However, prior to the rise of modern states in eastern Europe, the ability of the Orthodox Church to exercise nominal authority over the act of marriage was limited, and laymen usually officiated at marriage ceremonies (see, for example, Freeze 1990 on the Russian Empire).

5 Projections by Kaufmann, Goujon, and Skirbekk (2012) suggest that under certain scenarios the share of religious persons might even rise again in the future in some European countries, even if secularization trends continue at the individual level. The underlying mechanism would be compositional effects stemming from higher fertility among religious groups and in-migration from less-secularized countries.

6 An interesting case study is presented by Kolbe (2002), who contrasted labor market policies in Sweden and West Germany. She showed that the Swedish government promoted female employment by, for example, financing scientific studies which concluded that maternal employment is not harmful to child development. West Germany, on the other hand, aimed to limit female employment, and financed studies which came to the conclusion that maternal employment was harmful to child development.

7 Kalmijn (2011: 288) points out that these effect are strong for the decision whether to enter in a cohabitation or a marriage, while they are weaker for the transition from cohabitation to marriage.

8 We use the data for Germany somewhat reluctantly due to concerns about the representativeness of the union and fertility history data in the German GGS (Kreyenfeld, Hornung, and Kubisch 2013). However, these concerns relate primarily to the life his- 
tories of older cohorts and not to those who were of childbearing age during our period of interest (Vergauwen, Wood, and Neels 2013).

9 The collection of the attitude data from social contacts of respondents is so time and cost-intensive that it can usually only be obtained for small non-representative samples.

10 For example, in 2007 the population size of the 292 NUTS 2 regions (excluding Turkey) ranged from 26,923 to 11.6 million, with 24 percent of the regions having populations below the 800,000 threshold used to differentiate between NUTS 2 and NUTS 3 regions.

11 An alternative approach would be to not take the national level values and use the mean value of the subnational regions instead. However, the disadvantage with the latter is that it does not control for the population size of the regions, which tends to give regions with below-average population sizes too much weight.

12 However, in the case of the United Kingdom this is mostly due to Northern Ireland, where religion is given much more importance than in other parts of the country.

13 The results are available upon request from the authors.

14 Though a state-level analysis for the United States by Lesthaeghe and Neidert (2006) shows that at this level of aggregation evidence for the SDT is visible as well. 


\section{References}

Agresti, Alan 2002. Categorical data analysis. Second Edition. New York: Wiley.

Becker, Gary 1981. A treatise on the family. London/Cambridge: Harvard University Press.

Berghammer, Caroline. 2012. "Family life trajectories and religiosity in Austria. European Sociological Review 28(1): 127-144.

Billari, Francesco C. 2005. "Partnership, childbearing and parenting: trends of the 1990s," in United Nations Economic Commission for Europe (ed.), The New Demographic Regime: Population Challenges and Policy Responses. New York and Geneva: United Nations, pp. 63-94.

Billy, John O.G. and David E. Moore. 1992. "A multilevel analysis of marital and nonmarital Fertility in the U.S," Social Forces 70(4): 977-1011.

Bongaarts, John and Susan C. Watkins. 1996. Social interactions and contemporary fertility transitions. Population and Development Review 22(4): 639-682.

Bordieu, Pierre and Loïc J.D. Wacquant. 1992. An Invitation to Reflexive Sociology. Chicago: University of Chicago Press.

Bryan, Mark L. and Stephen P. Jenkins. 2013. Regression analysis of country effects using multilevel data: A cautionary tale. Institute for Social and Economic Research. University of Essex.

Bronfenbrenner, Urie and Pamela A. Morris. 2006. "The Bioecological Model of $\mathrm{Hu}-$ man Development," in William Damon and Richard M. Lerner (eds.), Handbook of Child Psychology (6 ${ }^{\text {th }}$ ed., Vol. 1). New York: Wiley, pp. 993-1028.

Buitendag, Johan 2008. "Marriage in the theology of Martin Luther - worldly yet sacred: An option between secularism and clericalism," HTS Theological Studies 63(2): 445-461.

Bumpass, Larry L. 1990. "What's happening to the family? Interactions between demographic and institutional change," Demography 27(4): 483-498.

Calvin, John. 1845. Institutes of the Christian religion (translated by Henry Beveridge). Edinburgh: Calvin Translation Society.

Coale, Ansley J. 1973. "The demographic transition reconsidered," in International Union for the Scientific Study of Population (IUSSP) (ed.), Proceedings of the In- 
ternational Population Conference 1973 1. Liege: International Union for the Scientific Study of Population, pp. 53-72.

Coale, Ansley J. and Susan C. Watkins. 1986. The Decline of Fertility in Europe. Princeton: Princeton University Press.

Coester, Michael. 1993. "Entwicklungslinien im europäischen Nichtehelichenrecht," Zeitschrift für Europäisches Privatrecht 1: 536-553.

Decroly, Jean-Michel and Claude Grasland. 1993. "Boundaries, political systems and fertility in Europe," Population: An English Selection 5: 101-119.

Esping-Andersen, Gøsta. 1999. Social Foundations of Post-Industrial Economies. Oxford: Oxford University Press.

Esping-Andersen, Gøsta. 2009. The incomplete revolution. Adapting to women's new roles. Cambridge: Polity Press.

Esping-Andersen, Gøsta and Francesco C. Billari. 2012. Re-theorizing Family Demographics. [unpublished manuscript].

Esteve, Albert, Ron Lesthaeghe, and Antonio López-Gay. 2012. "The Latin American cohabitation boom, 1970-2007," Population and Development Review 38(1): $55-81$.

Finke, Roger and Amy Adamczyk. 2008. Cross-national moral beliefs: The influence of national religious context," The Sociological Quaterly 49(4): 617-652.

Freeze, Gregory L. 1990. "Bringing order to the Russian family: Marriage and divorce in Imperial Russia, 1760-1860," The Journal of Modern History 62(4): 709-746.

Generations and Gender Programme (GGP-CDB). 2012. Generations and Gender Programme Contextual Database. «www.ggp-i.org/contextual-database.html». (distributor: Netherlands Interdisciplinary Research Institute. The Hague). Accessed 31 July 2012.

González Beilfuss, Cristina. 2005. Spanien und Portugal. In Jens M. Scherpe and Nadjma Yassari. Die Rechtsstellung nichtehelicher Lebensgemeinschaften, Beiträge zum ausländischen und internationalen Privatrecht. Tübingen: Mohr und Siebeck, pp. 249-275.

Halman, Loek and Veerle Draulans. 2006. "How secular is Europe?” The British Journal of Sociology 57(2): 263-288. 
Hajnal, John. 1965. "European marriage pattern in perspective," in David V. Glass, David E.C. Eversley (eds.), Population in History. Essays in Historical Demography. London: Edward Arnold (Publishers) Ltd., pp. 101-143.

Kalmijn, Matthijs. 2011. “The influence of men's income and employment on marriage and cohabitation: testing Oppenheimer's theory for Europe. European Journal of Population 27(1): 269-293.

Kalmijn, Matthijs. 2013. "The educational gradient in marriage: A comparison of 25 European countries," Demography 50(4): 1499-1520.

Katz, Ruth. 2001. "Effects of migration, ethnicity and religiosity on cohabitation," Journal of Comparative Family Studies 32(4): 587-599.

Kaufmann, Eric, Anne Goujon, and Vegard Skirbekk. 2012. "The end of secularization in Europe? A socio-demographic perspective," Sociology of Religion 73(1): 6991.

Kiernan, Kathleen. 2004. "Unmarried cohabitation and parenthood in Britain and Europe," Law \& Policy 26: 33-55.

Klüsener, Sebastian, Brienna Perelli-Harris, and Nora Sánchez Gassen. 2013. "Spatial aspects of the rise of nonmarital fertility across Europe since 1960: The role of states and regions in shaping patterns of change," European Journal of Population 29(2): 137-165.

Klüsener, Sebastian, Karel Neels, and Michaela Kreyenfeld. 2013. "Family policies and the Western European fertility divide: Insights from a natural experiment in Belgium," Population and Development Review 39(4): 587-610.

Kolbe, Wiebke. 2002. Elternschaft im Wohlfahrtsstaat : Schweden und die Bundesrepublik im Vergleich 1945-2000. Frankfurt am Main: Campus.

Kohler, Hans-Peter, Francesco C. Billari, and José A. Ortega. 2002. "The emergence of lowest-low fertility in Europe during the 1990s," Population and Development Review 28(4): 641-680.

Konietzka, Dirk and Michaela Kreyenfeld. 2002. "Women's employment and nonmarital childbearing: A comparison between East and West Germany in the 1990s," Population 57(2): 331-357. 
Kreyenfeld, Michaela, Anne Hornung, Karolin Kubisch. 2013. "The German Generations and Gender Survey: Some critical reflections on the validity of fertility histories," Comparative Population Studies 38(1): 3-28.

Lesthaeghe, Ron. 1980. “On the social control of human reproduction,” Population and Development Review 6: 527-548.

Lesthaeghe, Ron. 1995. "The second demographic transition: An interpretation," in Karen 0. Mason and An-Magrit Jensen (eds.), Gender and Family Change in Industrialized Countries. Oxford: Clarendon Press, pp. 17-62.

Lesthaeghe, Ron. 2010. "The unfolding story of the Second Demographic Transition," Population and Development Review 36(2): 211-251.

Lesthaghe, Ron and Lisa Neidert. 2006. "The Second Demographic Transition in the United States: Exception or textbook example?" Population and Development Review 32(4): 669698.

Liefbroer, Aart and Francesco C. Billari. 2010. "Bringing norms back in: A theoretical and empirical discussion of their importance for understanding demographic behaviour," Population, Space and Place 16(4): 287-305.

McLaughlin, Eithne and Caroline Glendinning. 1994. "Paying for care in Europe: Is there a feminist approach?" in Linda Hantrais and Steen Mangen (eds.), Family Policy and the Welfare of Women. Loughborough: Cross-National Research Group, pp. 52-69.

Mills, Melinda and Hans-Peter Blossfeld. 2013. "The Second Demographic Transition meets globalization: A comprehensive theory to understand changes in family formation in an era of rising uncertainty," in Ann Evans and Janeen Baxter (eds.), Negotiating the Life Course: Stability and Change in Life Pathways. Dordrecht: Springer, pp. 9-33.

Ní Bhrolcháin, Márie and Éva Beaujouan. 2013. "Education and cohabitation in Britain: A return to traditional patterns?" Population and Development Review 39(3): 441-458.

Ono, Hiromi. 2003. “Women's economic standing, marriage timing, and cross-national contexts of gender," Journal of Marriage and Family 65(2): 275-286.

Openshaw, Stan. 1984. The Modifiable Areal Unit Problem. Concepts and Techniques. Modern Geography 38. Norwich: Geo Books. 
Oppenheimer, Valerie Kincade. 1994. "Women's rising employment and the future of the family in industrial societies," Population and Development Review 20(2): 293-342.

Perelli-Harris, Brienna and Nora Sánchez Gassen. 2012. "How similar are cohabitation and marriage? Legal approaches to cohabitation across Western Europe,” Рориlation and Development Review 38(3): 435-467.

Perelli-Harris, Brienna, Michaela Kreyenfeld, and Karolin Kubisch. 2010. Harmonized histories: Manual for the preparation of comparative fertility and union histories. Rostock. MPIDR Working Paper WP-2010-011.

Perelli-Harris, Brienna et al. 2010. "The educational gradient of childbearing within cohabitation in Europe," Population and Development Review 36(4): 775-801.

Perelli-Harris, Brienna et al. 2012. "Changes in union status during the transition to parenthood: An examination of 11 European countries," Population Studies 66(2): 167-182.

Sklar, June L. 1974. "The role of marriage behaviour in the demographic transition: The case of Eastern Europe around 1900," Population Studies 28(2): 231-247.

Snijders, Tom A.B and Roel J. Bosker. 1999. Multilevel Analysis. London: Sage Publications.

Sobotka, Tomáš. 2008. "Overview chapter 6: The diverse faces of the second demographic transition in Europe," Demographic Research 19: 171-224.

Stegmueller, Daniel. 2013. "How many countries for multilevel modelling? A comparison of frequentist and Bayesian approaches," American Journal of Political Science 57:748-761.

Thévenon, Oliver and Angela Luci. 2012. "Reconciling work, family and child outcomes: What implications for family support policies?" Population Research and Policy Review 31(6): 855-882.

Thornton, Arland, William G. Axinn, and Daniel H. Hill. 1992. "Reciprocal effects of religiosity, cohabitation, and marriage," American Journal of Sociology 98(3): 628-651.

Upchurch, Dawn M., Lee A. Lillard, and Constantijn W.A. Panis. 2002. "Nonmarital childbearing: Influences of education, marriage, and fertility," Demography 39: 311-329. 
Van de Kaa, Dirk. 1987. "Europe's second demographic transition," Population Bulle$\operatorname{tin} 42(1): 1-59$.

Van de Kaa, Dirk. 1994. "The second demographic transition revisited: Theories and expectations," in Gijs Beets, Hans van den Brekel, Robert L. Cliquet, Gilbert Dooghe, and Jenny de Jong Gierveld (eds.), Population and family in the Low Countries 1993: Late fertility and other current issues. NIDI/CBGS Publication, No. 30. Berwyn, Pennsylvania/Amsterdam: Swets and Zeitlinger, pp. 81-126.

Venger, Sonja. 2004. Gesetzliche Regelung der Rechtsverhältnisse nichtehelicher Lebensgemeinschaften: Zur Notwendigkeit und inhaltlichen Ausgestaltung eines solchen Gesetzes im Rechtvergleich mit den Regelungen in Frankreich, den Niederlanden, Belgien und Katalonien. Berlin: TENEA Verlag für Medien.

Vergauwen, Jorik, Jonas Wood, and Karel Neels. 2013. Quality of Demographic Data in GGS Wave 1. Antwerp: University of Antwerp. Unpublished Manuscript.

Vignoli, Daniele, Francesca Rinesi, and Eleonora Mussino. 2013. "A home to plan the first child? Fertility intentions and housing condition in Italy," Population, Space and Place 19(1), 60-71.

Village, Andrew, Emyr Williams, and Leslie J. Francis. 2010. "Living in sin? Religion and cohabitation in Britain 1985-2005," Marriage \& Family Review 46(6\&7), pp. $468-479$.

Watkins, Susan C. 1991. From Provinces into Nations: Demographic Integration in Western Europe, 1870-1960. Princeton: Princeton University Press.

Witte Jr., John. 2012. From Sacrament to Contract. Marriage, Religion, and Law in the Western Tradition. Second edition. Louisville: Westminster John Knox Press. 
Appendix 1 - Overview Countries and Regional Divisions

\begin{tabular}{ll}
\hline Country & Regional Division for contextual information \\
\hline Austria & NUTS 2: 9 states (Bundesländer) \\
\hline Belgium & NUTS 1: 3 regions (gewesten/régions) \\
\hline Bulgaria & NUTS 2 (division as existing before 2006): 6 planning regions (rajoni za planirane) \\
\hline Estonia & NUTS 0/1/2: one country \\
\hline France & NUTS 1: 8 regions (zone d'études et d'aménagement du territoire), oversea de- \\
& partments are excluded \\
\hline Germany & NUTS 1: 16 states (Bundesländer) \\
\hline Hungary & NUTS 2: 7 planning and statistical regions (tervezési-statisztikai régiók) \\
\hline Lithuania & NUTS 1: 5 regions (gruppi di regioni) \\
\hline Netherlands & NUTS 0/1/2: one country \\
\hline Norway & NUTS 0: one country \\
\hline Poland & NUTS 2: 7 regions (landsdeler) $2: 16$ regions (województwa) \\
\hline Romania & NUTS 2: 8 regions (regiuni) \\
\hline Russia & Equivalent to NUTS 1: 10 economic regions (ekonomicheskiye rayony) \\
\hline Spain & NUTS 1: 7 groups of autonomous communities (agrupación de comunidades autóno- \\
& mas) \\
\hline United Kingdom & NUTS 1: 12 regions (NUTS 1 statistical regions of England, Wales, Scotland and \\
Northern Ireland); in order to have regions with time-constant areas East of England \\
(UKH) and South East England (UKJ) were joint into one region for the analysis, as \\
territories had been exchanged between these two regions during the period obser \\
vation.
\end{tabular}


Appendix 2 - Codes of Regions

\begin{tabular}{|c|c|c|c|c|c|}
\hline$\overline{\text { AT11 }}$ & Burgenland & ES5 & East (Spain) & PL34 & Podlasie \\
\hline AT12 & Lower Austria & ES6 & South (Spain) & PL41 & Greater Poland \\
\hline AT13 & Vienna & ES7 & Canary Island (Spain) & PL42 & West Pomerania (Poland) \\
\hline AT21 & Carinthia & FR1 & $\begin{array}{l}\text { Île de France (incl. } \\
\text { Paris) }\end{array}$ & PL43 & Lubusz \\
\hline AT22 & Styria & FR2 & Bassin Parisien & PL51 & Lower Silesia \\
\hline AT31 & Upper Austria & FR3 & Nord-Par-de Calais & PL52 & Opole \\
\hline AT32 & Salzburg & FR4 & East (France) & PL61 & Kujawy-Pomerania \\
\hline AT33 & Tyrol & FR5 & West (France) & PL62 & Warmia-Masuria \\
\hline AT34 & Vorarlberg & FR6 & Southwest (France) & PL63 & Pomerania \\
\hline BE1 & Brussels & FR7 & Central East (France) & $\mathrm{RO} 11$ & North West (Romania) \\
\hline BE2 & Flanders & FR8 & Méditerranée & $\mathrm{RO} 12$ & Centre (Romania) \\
\hline BE3 & Wallonia & HU10 & Central Hungary & $\mathrm{RO} 21$ & North East (Romania) \\
\hline BG11 & North West (Bulgaria) & HU21 & Central Transdanubia & $\mathrm{RO} 22$ & South East (Romania) \\
\hline BG12 & North Central (Bulgaria) & HU22 & $\begin{array}{l}\text { Western Transdanu- } \\
\text { bia }\end{array}$ & $\mathrm{RO} 31$ & South Muntenia \\
\hline BG13 & North East (Bulgaria) & HU23 & $\begin{array}{l}\text { Southern Transdanu- } \\
\text { bia }\end{array}$ & $\mathrm{RO} 32$ & Bucharest-Ilfov \\
\hline BG21 & South West (Bulgaria) & HU31 & Northern Hungary & RO41 & South West Oltenia \\
\hline BG22 & South Central (Bulgaria) & HU32 & Northern Great Plain & $\mathrm{RO} 42$ & West \\
\hline BG23 & South East (Bulgaria) & HU33 & Southern Great Plain & RU1 & $\begin{array}{l}\text { North and North West } \\
\text { (Russia) }\end{array}$ \\
\hline DE1 & Baden-Württemberg & ITC & Northwest (Italy) & RU2 & Centre (Russia) \\
\hline DE2 & Bavaria & ITD & Northeast (Italy) & RU3 & Volgo-Vyatsky \\
\hline DE3 & Berlin & ITE & Central (Italy) & $\mathrm{RU} 4$ & Central Black Earth \\
\hline DE4 & Brandenburg & ITF & South (Italy) & RU5 & Volga \\
\hline DE5 & Bremen & ITG & Islands (Italy) & RU6 & North Caucasus \\
\hline DE6 & Hamburg & LT & Lithuania & RU7 & Urals \\
\hline DE7 & Hessen & $\mathrm{NL}$ & Netherlands & RU8 & Western Siberia \\
\hline DE8 & $\begin{array}{l}\text { Mecklenburg-Western Pom- } \\
\text { erania }\end{array}$ & NO01 & Oslo and Akershus & RU9 & Eastern Siberia \\
\hline DE9 & Lower Saxony & $\mathrm{NO} 02$ & Hedmark and Oppland & RUA & Far East \\
\hline DEA & North Rhine-Westphalia & $\mathrm{NO03}$ & Sør-Østlandet & UKC & North East (England) \\
\hline DEB & Rhineland-Palatinate & NO04 & Agder and Rogaland & UKD & North West (England) \\
\hline DEC & Saarland & NO05 & Vestlandet & UKE & Yorkshire and the Humber \\
\hline DED & Saxony & NO06 & Trøndelag & UKF & East Midlands \\
\hline DEE & Saxony-Anhalt & NO07 & Nord-Norge & UKG & West Midlands \\
\hline DEF & Schleswig-Holstein & PL11 & Łódz & UKHJ & $\begin{array}{l}\text { East and South East } \\
\text { (England) }\end{array}$ \\
\hline DEG & Thuringia & PL12 & Mazovia & UKI & London \\
\hline EE & Estonia & PL21 & Lesser Poland & UKK & South West (England) \\
\hline ES1 & Northwest (Spain) & PL22 & Silesia & UKL & Wales \\
\hline ES2 & Northeast (Spain) & PL31 & Lublin & UKM & Scotland \\
\hline ES3 & Madrid & PL32 & Subcarpathia & UKN & Northern Ireland \\
\hline ES4 & Centre (Spain) & PL33 & Świętokrzyskie & & \\
\hline
\end{tabular}




\section{Appendix 3 - Contrasting Different Measures of Contextual Covariates}

Figure 3A: Regional Variation in Social Disapproval of Nonmarital Childbirth and Social Disapproval of Cohabitation

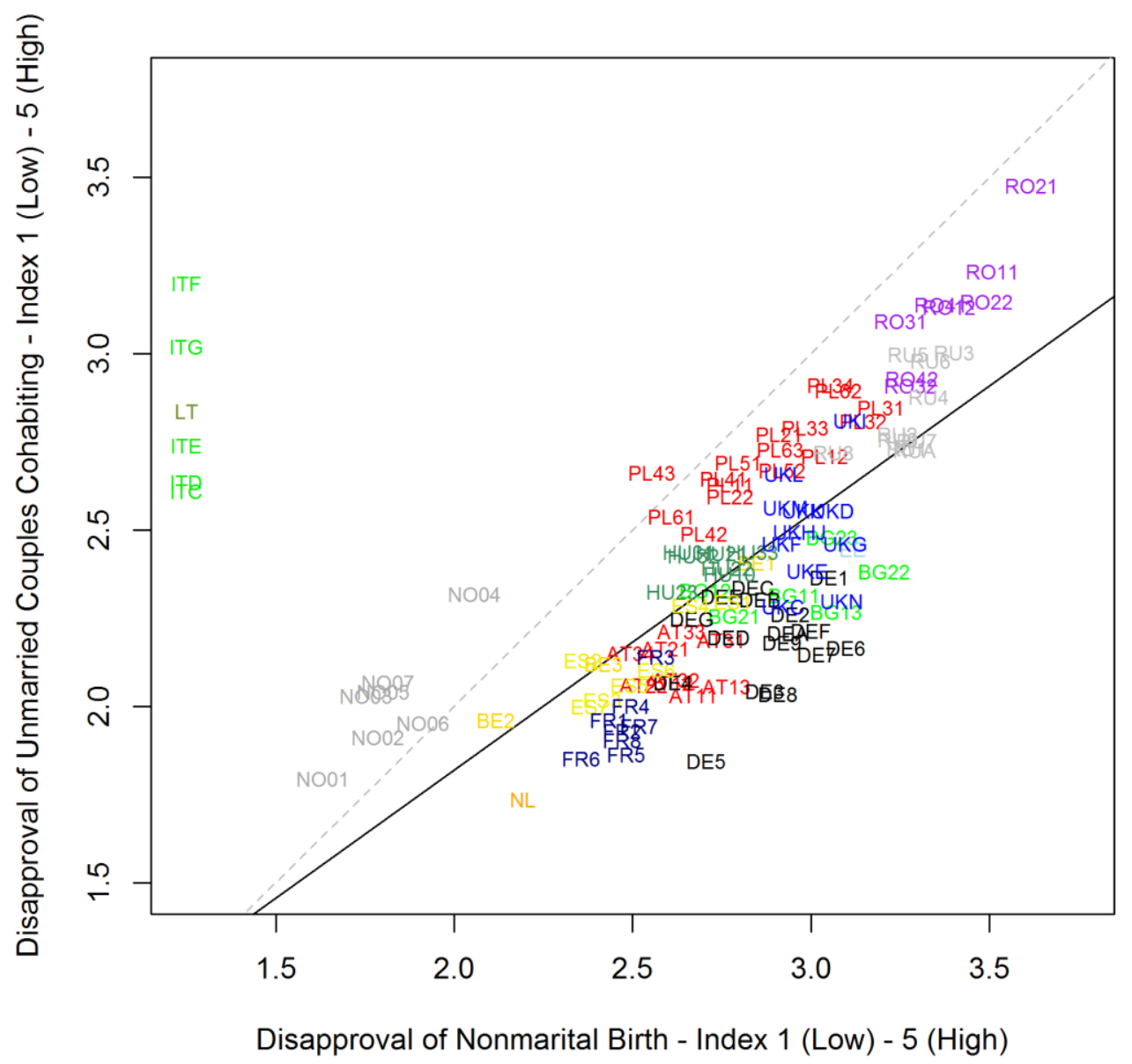

AT: Austria; BE: Belgium; BG: Bulgaria; DE: Germany; EE: Estonia; ES: Spain; FR: France; HU: Hungary; IT: Italy; LT: Lithuania; NL: Netherlands; NO: Norway; PL: Poland; RO: Romania; RU: Russia; UK: United Kingdom. Region names can be obtained via Appendix 2.

Note: For the Italian regions and Lithuania information on disapproval of nonmarital births is not available only level of disapproval of unmarried people cohabiting is displayed (on the $y$-axis on the left side of the plot).

Source: ESS Wave 3, EVS Wave 4, GGP Wave 1, own calculations 
Figure 3B: Regional Variation in Share without Religion and Share not Religious

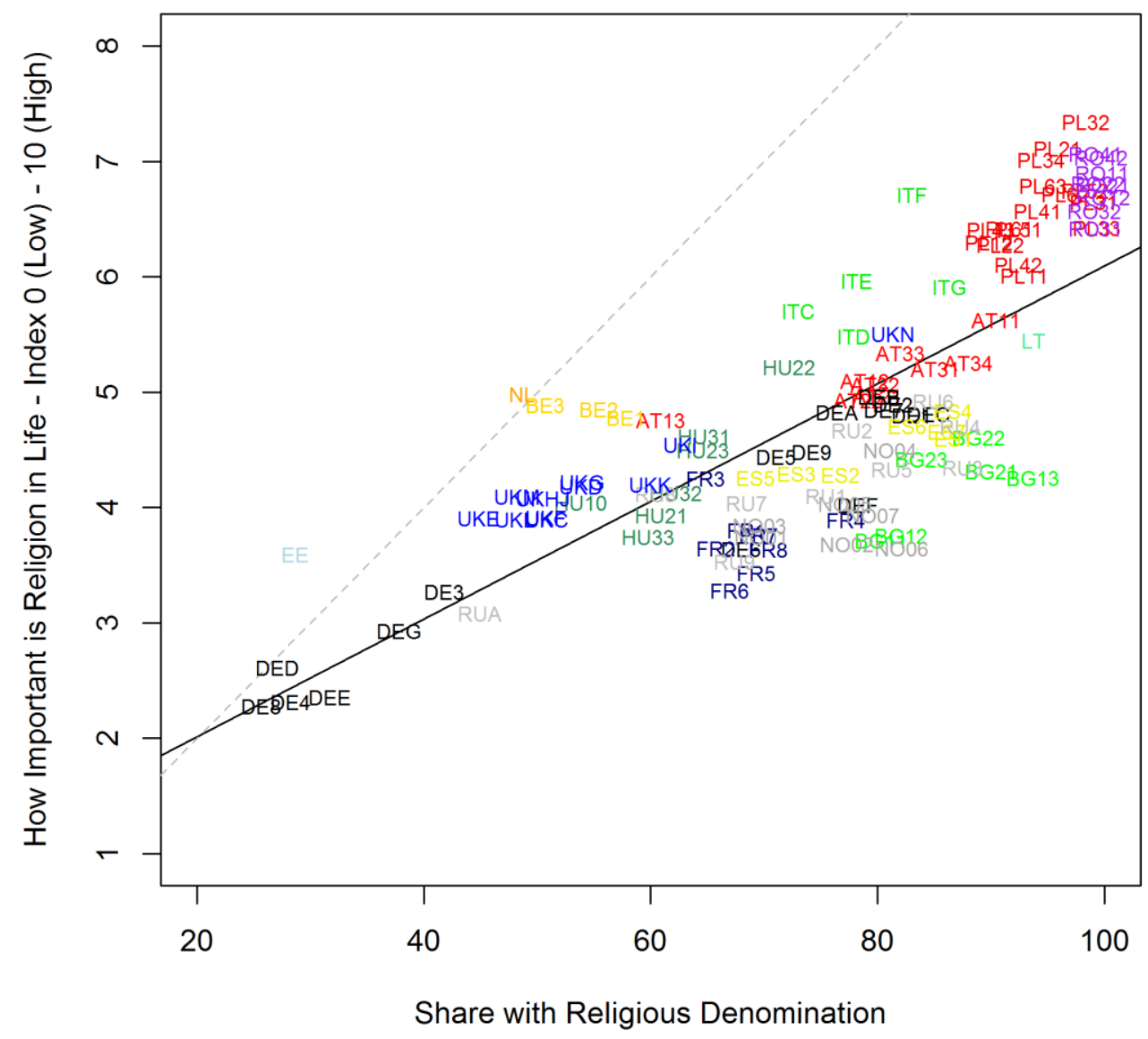

AT: Austria; BE: Belgium; BG: Bulgaria; DE: Germany; EE: Estonia; ES: Spain; FR: France; HU: Hungary; IT: Italy; LT: Lithuania; NL: Netherlands; NO: Norway; PL: Poland; RO: Romania; RU: Russia; UK: United Kingdom. Region names can be obtained via Appendix 2.

Source: ESS Wave 1-4, EVS Wave 3-4, GGP Wave 1, own calculations 
Figure 3C: Regional Variation in Perceptions on Female Employment Rate and Female Economic Autonomy

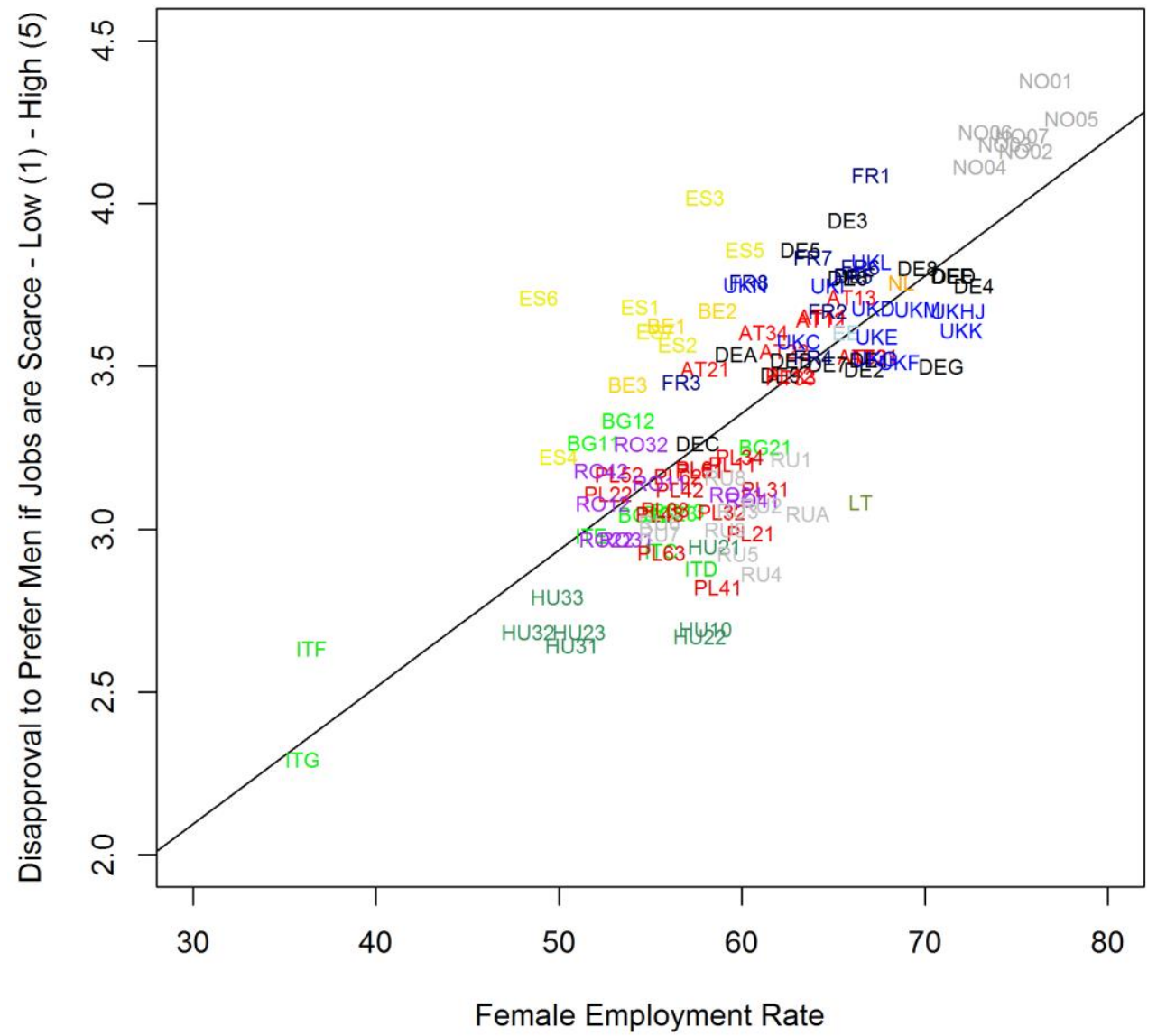

AT: Austria; BE: Belgium; BG: Bulgaria; DE: Germany; EE: Estonia; ES: Spain; FR: France; HU: Hungary; IT: Italy; LT: Lithuania; NL: Netherlands; NO: Norway; PL: Poland; RO: Romania; RU: Russia; UK: United Kingdom. Region names can be obtained via Appendix 2.

Source: Eurostat, ESS Wave 2 and 4, GGP Wave 1, own calculations 
Figure 3D: Regional Variation in Adult and Youth Unemployment Rates 2003

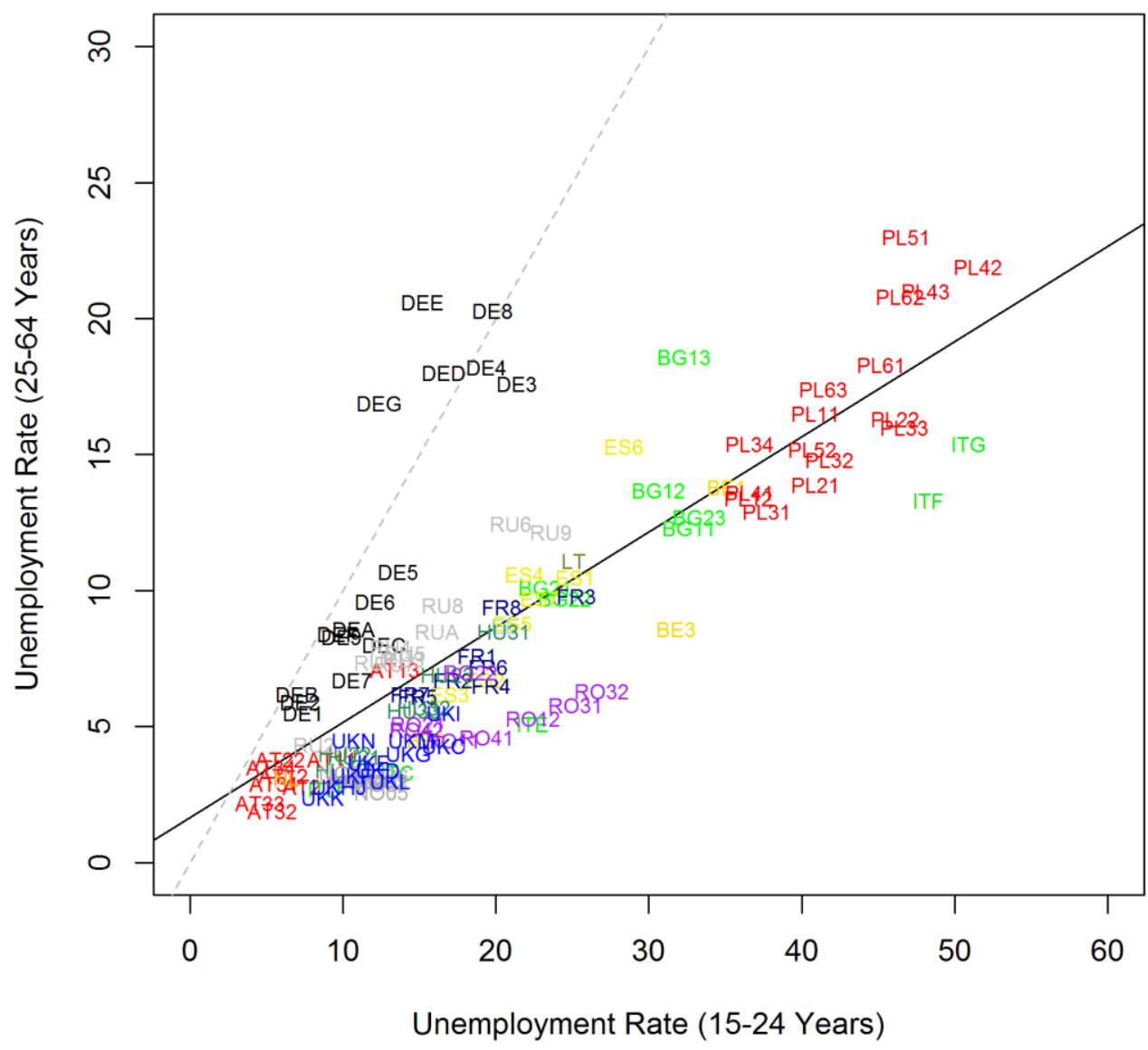

AT: Austria; BE: Belgium; BG: Bulgaria; DE: Germany; EE: Estonia; ES: Spain; FR: France; HU: Hungary; IT: Italy; LT: Lithuania; NL: Netherlands; NO: Norway; PL: Poland; RO: Romania; RU: Russia; UK: United Kingdom. Region names can be obtained via Appendix 2.

Source: GGP-CDB, Eurostat (EU-SILC) 